\title{
Notes
}

\section{The Legitimacy of Civil Law Reasoning in the Common Law: Justice Harlan's Contribution}

\section{I}

Theorists of the common law have long proclaimed its unifying and comprehensive qualities. ${ }^{1}$ Coke took the position that any judicial decision was but an attempt to attain harmony with "the law," although any given precedent might be held to be contrary to "the law" if it could be shown that the rule established by that precedent had inconvenient consequences. ${ }^{2}$ By the eighteenth century this conception had become firmly rooted in our jurisprudence, as evidenced by Blackstone's view of the common law as a fully matured and selfsufficient legal system. ${ }^{3}$ Later commentators detected a sort of internal dynamics of the common law, propelling courts and judges inevitably toward correct solutions of the cases before them. ${ }^{4}$ Thus, traditional common law theory has resembled a sort of legal Platonism, by which some ideal form of "the law," conceived of as a complete entity, ${ }^{5}$ is deemed to exist in the heavens and to guide the decisions of our earthly courts.

1. See Lincoln, The Relation of Judicial Decisions to the Law, 21 HAkv. L. REV. 120 (1907).

2. See E. CoKE, INstitutes $* 379$ a.

3. See I W. Blackstone, Commentaries *69, 70 .

4. Fuller, for example, saw the law moving toward some central theory inlierent in the law itself. See L. FULLER, THE LAw in QUEST OF ITSELF (1940). Llewellyn, in this same vein, seemed to believe that the logic of the common law could make solutions virtually leap from difficult cases. See K. Llewelly, The Common Law Tradition: Degiding Appeals 178-99 (1960). Indeed, there is much in Anglo-American legal history that regards the common law as a "brooding omnipresence in the sky," Southern l'acific Co, v. Jenson, 244 U.S. 205, 222 (1917) (dissenting opinion), despite Justice Holmes's disclatimer. Holdsworth, after all, believed that the common law system owed its vitality to the eighteenth century philosophy that "judicial decisions are but evidence of the law which is sometimes misrepresented by a bad precedent." Stone, The Common Law in the Unitch States, 50 Harv. L. REv. 4, 8 (1936), citing Holdsworth, Case Law, 50 L.Q. REv، 180 (1980). This same philosophy found early expression in the United States Supreme Court wheil, in the famous case of Swift $v$. Tyson, Justice Story declared:

In the ordinary use of language it will hardly be contended that the decisions of

Courts constitute laws. They are, at most, only evidence of what the laws are and

are not of themselves laws. They are often re-examined, reversed, and qualificd by

the courts themselves, whenever they are found to be either defective or ill-founded, or otherwise incorrect.

41 U.S. (16 Pet.) 1, 18 (1842).

5. See Carpenter, Court Decisions and the Common Law, 17 Colum. L. REv. 593 (1917). 
The various orthodox theories of the common law as a harmonious and fully integrated legal system, however, generally have one conspicuous omission: a satisfactory account of the role of legislation. In a system which owes its success to dispassionate reasoning by analogy from prior judicial decisions, the element of legislation, constrained by neither reason nor disinterestedness, must necessarily be regarded as foreign.

In 1908, Roscoe Pound was led to remark:

Not the least notable characteristics of American law today are the excessive output of legislation in all our jurisdictions and the indifference, if not contempt, with which that output is regarded by courts and lawyers. Text-writers who scrupulously gather up from every remote corner the most obsolete decisions and cite all of them, seldom cite any statutes except those landmarks which have become a part of our American common law, or, if they do refer to legislation, do so through the judicial decisions which apply it. The courts, likewise, incline to ignore important legislation ....

Pound's remarks echoed an earlier observation by Sir Francis Pollock: that there seemed to be no way to account for the rules of statutory interpretation followed by the English courts of his day,

except on the theory that Parliament generally changes the law for the worse, and that the business of the judge is to keep the mischief of its interference within the narrowest possible bounds. ${ }^{7}$

The orthodox view of Anglo-American jurisprudence has thus been to regard statutes as aberrational departures from the orderly development of the common law, rather than as sources of law to be reasoned from and developed in the same manner as judicial precedents.

In the present century, however, this orthodox view has been heavily strained. Whole new areas of law have developed from statutory origins, while in numerous other areas legislative enactment has almost entirely displaced the common law. ${ }^{8}$ These developments

6. Pound, Common Law and Legislation, 21 Harv. L. Rev. 383 (1908).

7. F. Pollock, Essays in Jurisirudence and Ethics 85 (1882). Sec also W. Blacistone, Commentaries $* 70$.

8. The areas of antitrust and labor relations are among the most familiar instances in which a whole body of law has been built around legislation. In the conmercial law area, the Uniform Commercial Code, though in part the result of an cffort to codify common law principles, has served to displace those principles as independent sources of law. 
alone strongly suggest the necessity for a reappraisal of legislation's role in the American legal system. In addition, two opinions delivered by Justice Harlan on June 15, 1970, in Welsh v. Uniled States $^{9}$ and Moragne $v$. States Marine Lines, Inc. ${ }^{10}$ suggest that this very process of reappraisal may have already begun.

\section{II}

In Moragne, Justice Harlan wrote for a unanimous Court and held that the general maritime law incorporates a wrongful death action for violations of the maritime duty of seaworthiness. ${ }^{11}$ The reasoning by which Justice Harlan reached this conclusion, rather than the conclusion itself, is of particular interest here. To appreciate the methodology he employed, the facts and surrounding circumstances of the case must be thoroughly understood.

Moragne presented the Court with what can only be described as an anomaly in the law. The petitioner was the widow of a longshoreman killed aboard a vessel in the coastal waters of Florida. In a wrongful death action she alleged that her husband's denth was caused by the unseaworthiness ${ }^{12}$ of the vessel on which he was working. The anomaly that the Court faced arose from the peculiar history of wrongful death recovery in admiralty. As in shoreside common law, ${ }^{13}$ there had traditionally been no right of recovery for wrongful death in admiralty. ${ }^{14}$ By the time of Mrs. Moragne's action, however, all fifty states had enacted wrongful death statutes ${ }^{\mathbf{1 5}}$ patterned after Lord Campbell's Act. ${ }^{16}$ Yet, in admiralty the existence of a statutory remedy for wrongful death was not always certain. The Death on the High Seas Act, ${ }^{17}$ enacted in 1920, provided a right of recovery for any death resulting from the breach of either the duty of ordinary care or the duty to maintain a seaworthy vessel "occurring

\footnotetext{
9. 398 U.S. $333(1970)$.

10. 398 U.S. $375(1970)$.

11. Id. at 469 .

12. Seaworthiness is a special maritime duty of carc, stricter than the negligence standard of ordinary care, and owed exclusively to seamen and longshoremen. See gen. erally G. GILMORE \& C. BLACK, THE LAW OF ADMIRALTY 315-32 (1957).

13. Insurance Co. v. Brame, 95 U.S. 754 (1878). See generally 2 F. HARi'ER \& F. JAMEs, THE LAw OF TORTS 1284-85 (1956).

14. The Harrisburg, 119 U.S. 199 (1886). See G. GiLmore \& C. Black, supra note 12, at 302.03 .

15. See Smith, Wrongful Death Damages in North Carolina, 44 N.C.L. REv. 402, 409 (1966).

16. 9 \& 10 Vict., c.93 (1846).

17. 46 U.S.C. $\$ \$ 761-68$ (1970).
} 
on the high seas beyond a marine league from shore."18 Wilhin a marine league of the shore, however, recovery was usually dependent on the wrongful death statute of the state in whose waters the accident had occurred. ${ }^{19}$ Since all such state statutes incorporate the negligence standard of ordinary care, ${ }^{20}$ death caused by a breach of that duty occurring in state territorial waters would always give rise to an action. Not all state wrongful death statutes, however, incorporate the maritime duty of seaworthiness; hence the existence of a right to recover for breach of that duty depends on which state is involved. In wrongful death cases prior to Moragne, the applicable state wrongful death statutes had all been found to incorporate the maritime duty of seaworthiness. ${ }^{21}$ But, as was bound to happen, Mrs. Moragne asserted her claim under a statute which was found nol to incorporate that duty. ${ }^{22}$ The Florida Supreme Court had squarely held that the state's wrongful death act incorporated only the duty to use ordinary care.

Hence, the anomalous gap into which longshoreman Moragne fell: If the accident had taken place outside the one marine league limit, recovery would have been available under the Death on the High Seas Act. If the accident had occurred within the coastal waters of an adjoining state whose wrongful death statute incorporated the maritime duty of seaworthiness, recovery would again have been available. If the accident had resulted from the breach of the duty to use ordinary care, recovery could have been had under the Florida Act itself.

18. Although the Death on the High Seas Act, 46 U.S.C. $\$ \$ 761.68$ (1970), applies only to death "caused by wrongful act, neglect, or default," id. at $\$$;0l, it has been construed to provide a remedy for death resulting from either negligence or unseavorthiness. Sce, e.g., Symonette Shipyards Ltd. v. Clark, 365 F.2d 164 (J̈th Cir.), cert. denied, 387 U.S. 903 (1966).

19. Western Fuel Co. v. Garcia, 257 U.S. 233, 242 (1922). The Jones Act, 46 U.S.C. $\$ 688$ (1970), provides a wrongful death remedy for seamen (but not for longshoremen) in actions based upon negligence (but not upon unscaworthincss) in state territorial waters and on the high seas (beyond one marine league from the shore).

20. See F. HARPER \& F. JAMES, supra note 13, at 1289.

21. See, e.g., Louisiana: Grigsby v. Coastal Marine Service of Texas, Inc., 412 F.2d 1011, $1024-29$ (5th Cir. 1969); California: Curry v. Fred Olsen Line, 367 F.2d 921, 926 (9th Cir. 1966), cert. denied, 386 U.S. 971 (1967); Puerlo Rico: Compania Transatlantica Espanola SA v. Melendez Torres, 358 F2d 209, 213 (1st Cir. 1966); South Carolina: E. A. Anthony v. International Paper Co., 289 F.2d 574, 578-79 (4th Cir. 1961); rirginia: Holle) v. The Manfred Stansfield, 269 F.2d 317, 321 (4th Cir.), cert. denied sub nom. Reederei Blumenfeld, G.M.B.H. v. Holley, 361 U.S. 883 (1961); W'est I'irginia: Union Carbide Corp. v. Goett v. Amherst Barge Co., 278 F.2d 319, 321 (4ut Cir.), cert. denied, 36t U.S. 826 (1960); Michigan: Hunter v. Dampsk A/S Flint v. Detroit Marine Terminals, Inc., 279 F. Supp. 701, 703 (E.D. Mich. 1967); Oregon: Tallmon v. Toko Kaium K.K. Kobe, 278 F. Supp. 452, 456 (D. Ore. 1967); Maryland: Metzger v. S.S. Kirsten Torm. 24J F. Supp. 227, 230-31 (D. Md. 1965); New York: Clark v. Iceland S.S. Co., G A.D.2d 544, 549, 179 N.Y.S.2d 708, 715 (1958).

22. Moragne v. States Marine Lines, Inc, 211 So. 2 d 161, 167 (Fla. 1968). 
Finally, if Moragne's accident had resulted only in injury short of death, he would have had a cause of action based on unsenworthiness under general maritime law. ${ }^{23}$ Thus, no remedy was available for one class, composed of seamen and longshoremen, whose deaths resulted from a breach of the duty of seaworthiness in the waters of a state whose wrongful death statute happened to not incorporate that standard. ${ }^{24}$

Facing such an anomaly, the Court might have based its decision on either of two modes of analysis. First, the Court might have uscd something like a traditional equal protection analysis, asking whether such disparity of treatment was rationally related to the purpose of compensating relatives of those wrongfully killed. Not surprisingly, however, the Court did not take this route. The parties had not conceived of the case in equal protection terms, nor did the Court explicitly so view it. ${ }^{25}$ Second, the Court might have reconsidered the admiralty rule denying a general wrongful death remedy-rooted as such denial was in the old common law felony-merger doctrine ${ }^{20}$ and found that rule to lack present justification in fact or reason.97

While acknowledging the force of this second mode of analysis in support of its holding, ${ }^{28}$ the Court was not content to rest its decision solely upon it. It looked to the trend of legislative enactment for additional guidance. It noted that every state had enacted a wrongful death statute and that Congress had provided such actions for railroad employees in the Federal Employers' Liability Act, ${ }^{20}$ for all seamen in the Jones Act, and, indeed, for all persons killed on the high seas

23. See G. Gilmore \& C. BLACK, supra note 12, at 315 .

24. In fact, as the Florida Supreme Court noted, longshoreman Moragne probably did have a remedy under the Longshoremen's and Harbor Workers' Compensation $\Lambda$ ct, 33 U.S.C. $\$ \$ 901-50(1970)$, a federal maritime workmen's compensation act. Although it is not clear, it appears that the petitioner waived this remedy and elected to pursile her maritime "common law" claim for breach of the duty of seaworthiness. See Morngute v. States Marine Lines, Inc., 211 So. 2d 161, 163 (Fla. 1968). If Moragne had becn a scatman rather than a longshoreman, however, this remedy, as well as all other stattitory remedies, would have been unavailable.

25. Although the Court did not explicitly view the case in equal protection terms, the mode of analysis it used may ultimately have resembled that of equal protection. See p. 277 infra.

26. By this ancient doctrine the negligent killing of another was both a tort and a felony. The felony was regarded as more important, however, and was punishable by death and forfeiture of all the felon's property to the Crown. With all the property thiss forfeited, nothing remained on which to base a civil stit. See E. l'ollock, Law of ToRTs 52.57 (Landon ed. 1951).

27. Quite apart from a general assault on the common law rule against recovery for wrongful death, the Court might have focused on the advisability of retaining the old common law rule in admiralty. Indeed, it had once been held that the admiralty was frec to adopt its own rule respecting wrongful death recovery irrespective of the common law rule. See, e.g., The Sea Gull, 21 F. Cas. 909 (No. 12,578) (C.C. Md. 1865).

28. See 398 U.S. at 381-88.

29. 45 U.S.C. $\$ \$ 51-59(1970)$. 
in the Death on the High Seas Act. Although none of these statutes expressly offered petitioner any relief, the Court chose to read them together, and in so doing, found in the whole something greater than the sum of its parts:

These numerous and broadly applicable statutes, taken as a whole, make it clear that there is no present public policy against allowing recovery for wrongful death. . . . This legislative establishment of policy carries significance beyond the particular scope of each of the statutes involved. The policy thus established has become itself a part of our law, to be given its appropriate weight not only in matters of statutory construction but also in those of decisional law. ${ }^{30}$

Clarifying the presumption underlying its analysis, the Court went on to state:

In many cases the scope of a statute may reflect nothing more than the dimensions of the particular problem that came to the attention of the legislature, inviting the conclusion that the legislative policy is equally applicable to other situations in which the mischief is identical. This conclusion is reinforced where there exists not one enactment but a course of legislation dealing with a series of situations, and where the generality of the underlying principle is attested by the legislation of other jurisdictions. ${ }^{31}$

By thus finding in a series of statutes a clear affirmative policy favoring wrongful death recovery, the Court was persuaded to overturn its own prior judicially-created doctrine and to provide Mrs. Moragne with a remedy.

The first observation to be made about the Court's reasoning is that it flies directly in the face of a good deal of received learning about common law judicial views of legislation.32 The second and more important observation, however, is that Harlan's opinion for the Court utilized a legal methodology which explicitly recognized the genera. tive capacity of legislation.

\section{III}

In support of his methodology, Justice Harlan cited only four authorities: law review articles by Roscoe Pound ${ }^{33}$ and James Landis, ${ }^{3-1}$

30. 398 U.S. at $390-91$ (emphasis added).

31. Id. at 392.

32. See p. 260 supra.

33. Pound, Comment on the Death Statules-Applicability to Dealh in Admiralty, 13 NACCA L.J. 188 (1954).

34. Landis, Statutes and the Sources of Law, in Harvard Legal Essars 213 (1934). 
dictum from a 1924 dissenting opinion of Justice Holmes, ${ }^{\text {as }}$ and a 1955 Supreme Court decision which offered only limited support for the far-reaching methodology of the Court. ${ }^{30}$ Credit for the methodology of the Harlan opinion truly belongs to Pound and Landis. In 1908 Pound wrote a seminal article, ${ }^{37}$ attacking the shortsightedness of the orthodox common law view of legislation, tracing its origins to certain political and intellectual developments of the nineteenth century, and essentially arguing for its abandonment. Pound's classic presentation drew little attention until the constitutional crisis of the 1930's when Landis wrote his landmark essay, "Statutes and the Sources of Law."38 These two articles noted that the common law's refusal to regard statutes as analogical sources of law similar to judicial precedent was contrary to the practice in many civil law systems. Indeed, the articles of Pound and Landis demonstrated that the common law itself owed many of its major developments to a liberal treatment of legislative material resembling that of civil law systems.

Pound conceived of at least four ways in which common law courts might treat legislative material:

(1) They might receive it fully into the body of the law as afford. ing not only a rule to be applied but a principle from which to reason, and hold it, as a later and more direct expression of the general will, of superior authority to judge-made rules on the same general subject; and so reason from it by analogy in preference to them. (2) They might receive it fully into the body of the law to be reasoned from by analogy the same as any other rule of law, regarding it, however, as of equal or co-ordinate authority in this respect with judge-made rules upon the same general subject. (3) They might refuse to receive it fully into the body of the law and give effect to it directly only; refusing to

35. [I]t seems to me that courts in dealing with statutes sometimes have been too slow to recognize that statutes even when in terms covering only particular cases may imply a policy different from that of the common law, and thercfore may cxclude a reference to the common law for the purpose of limiting their scope.

Panama R.R. v. Rock, 266 U.S. 209, 216 (1924).

36. Cox v. Roth, 348 U.S. 207 (1955), centered on the question of whether an action under the Jones Act survives the death of the tortfeasor shipowner. The problen confronting the Court was that the Jones Act extended to seamen the same rights granted to railway employees by the Federal Employers' Liability Act, 45 U.S.C. $\$ \$ 51.59$ (1970), which contained no specific provision for the survival of actions against deceascd tortfeasors. But, noting that FELA allowed the prosecution of wrongful death claims against "the receiver or receivers or other persons or corporations charged with the duty of the management and operation of the business of a common carrier," id. $\$ 57$, the Court reasoned that since receivership was the "corporate analogue" of death, an action would still lie against the personal representative of the deceased shipowner. 348 U.S. at 209.

37. Pound, supra note 6.

38. Landis, supra note 34 . 
reason from it by analogy but giving it, nevertheless, a liberal interpretation to cover the whole field it was intended to cover. (4) They might not only refuse to reason from it by analogy and apply it directly only, but also give to it a strict and narrow interpretation, holding it down rigidly to those cases which it covers expressly. ${ }^{33}$

He argued that common law jurisprudence was slowly evolving away from the orthodox position embodied in the fourth method toward ultimate adoption of the method embodied in the first. Though we have certainly not reached the stage of legal development described in Pound's first proposition, the Moragne opinion is at least an approach toward, if not an application of, that proposition.40

As Pound noted, reasoning by analogy from statutes strikes many trained in the common law as alien if not absurd. In the first place, the objection is made that statutes are the product, not of reasoned deliberation, but of clashes of interest in the legislative forum; that they contain compromise, not principle, and therefore ought not to be subjected to analogical extension. Furthermore, reasoning from statutes as sources of law assumes that they will have some permanency when, in fact, any statute can be amended or completely reversed by a succeeding legislature. These and other objections to the methodology of analogical reasoning from statutes will be considered again later. ${ }^{41}$ For the present, it is only necessary to point out that such objections have not inhibited the use of statutes as analogical sources in civil law systems of the European continent.

Civil law theorists, like their Anglo-American counterparts, have claimed a completeness and universality for their orm principles.42 Unlike the common law, however, the source of those legal principles is not judicial precedent, but rather a legislatively enacted civil code. ${ }^{43}$ In orthodox civil law theory, the statute is conceived of as "being the most satisfactory and perfect method of realizing justice," and as the

39. Pound, supra note 6, at 385-86.

40. In Moragne Justice Harlan argued that the trend of enactment of wrongful death legislation reflected a public policy which deserved to be given precedence over carlier judicially-created rules with respect to the same subject. See 398 U.S. at 390 . Such judicial deference to the generally expressed legislative will is preciscly that contemplated by Pound's first alternative methodology.

41. See pp. 279-80 infra.

42. "The term "civil law," as used herein, refers primarily to the legal systems of France and Germany though most of the discussion is true also of those other European legal systems which are derived, to a greater or lesser extent, from the ancient Roman Law. Of course, the "civil law" is not identical in any two European countries though certain methodological generalizations can be made. See F. LAvsoN, A Cousuox LAwyEs Looks at THE Civil LAw 2-10 (1953).

43. See Pound, Sources and Forms of Law, 22 Notre Dasie LAw. 1, 71-73 (1940). 
"unique source of judicial decisions." 44 When no rule can be found which expressly covers a particular problem, civil law courts seek to discern from a statute, or from a course of legislation, one or more principles which can be applied to situations substantially similar or analogous to (but not expressly covered by) the terms of the legislation. The formal concepts, in the German system, have been explained as follows:

The principles that are basic to the Code carry the germ of further development in themselves. This development is by way of analogy. If a case is not regulated in the law but a legally similar case is regulated, then this provision is decisive in the dcciding of the first case (Gesetzesanalogie). . . . If no result can be reached through this process of analogy, then the decision must be drawn from the spirit of the whole law (Recht) considered as one system (Rechtsanalogie).4َّ

Thus it can be seen that the Court's opinion in Moragne utilized a legal methodology very much akin to the accepted methodology of civil law jurisprudence, and, as will now be argued, not altogether foreign to the common law either.

Very early in the course of Anglo-American legal history, English courts developed a doctrine known as the "equity of a statute." 40 In this sense the term "equity" had a well-understood meaning in the law courts of England long before it came to refer to the doctrine of the Court of Chancery. By the doctrine of equity of a statute, asso-

44. Charmont \& Chausse, Les Interprêtes du Code Civil, in $1 \mathrm{LE}$ CovE Civil, 1801. 1904, Livge du Centenaire 133, 152-55 (1904), quoted in A. Von Meliken, Tile Givil. LAw System: CASES AND MATERIALS FOR THE COMPARATIVE Study OF LAW 60 (1957).

45. I Motive Zu DeM Entwurfe Eines Burgerlichen Geserziuciles Fur DAs Deutscill REICH 14-17 (1888), in VoN MEHREN, supra note 44, at 64.

In a very provocative article, The Ninth Amendment as Civil Latu Method and its Implications for Republican Form of Government: Gristold v. Connecticut; South Guro. lina v. Katzenbach, 40 Tur. L. Rev. 487 (1966), Professor Mitchell Franklin forccfully argues that Justice Douglas' majority opinion in Griswold v. Connecticut, 981 U.S. 479 (1965), employs the civil law methodology of Rechtsanalogie. Douglas, it will be recalled, contended that "penumbras" and "cmanations" from various constitutional amcndments implicitly sanctioned a right to privacy. In Franklin's words:

What Justice Douglas meant is that although the first, third, fourth, and fifth ancind. ments had no imperative force it was possible for him to project their total force beyond the texts themselves so as to derive a general principle stated it none of those amendments. He thus discovered a constitutional "right of privacy," thotigh, to repeat, such right could not be justified by genuine interpretation of any or all of the amendments in question.

40 TUL. L. Rev. 490-91.

46. See Loyd, The Equity of a Statute, 58 U. PA. L. REv. 76 (1909). 
ciated most closely with Coke and Plowden, the application of a statute might be judicially extended beyond its express terms, or restricted so as to exclude certain instances admittedly within its express terms. Plowden seemed to conceive of the doctrine as a means of effectuating legislative intent, ${ }^{47}$ while Coke viewed it more as a necessary corollary of the practical limitations upon legislatures, as a sort of ejusdem generis clause judicially appended to all legislation. ${ }^{44}$ However viewed, the doctrine of equity of a statute undoubtedly gave courts considerable freedom to derive and develop legal principles from rules of statutory origin.

By the eighteenth century, however, English courts had abandoned any claim to divine statutory equities. Landis argues that "[t]he reasons for this professed self-abnegation of power seem extrinsic rather than intrinsic to the nature of the law."19 Among the extrinsic factors he cites are the development of the doctrine of separation of powers, the corollary view of judges as passive agents "finding" the law, and finally the powerful influence of Blackstone and his view that the common law was already a fully matured and self-sufficient system..$^{50}$ These factors operated to push the "equity" doctrine into desuetude and to erect in its place the contrary principle that statutes in derogation of the common law are to be strictly construed.51

While the principle of strictly construing statutes was introduced early into American law ${ }^{52}$ and has remained a fundamental principle of our jurisprudence, ${ }^{, 3}$ our courts have accomplished a great deal that could have been subsumed under the prior "equity" doctrine. The judicial response to the Married Women's Acts of the nineteenth century is a notable example. The common law had relegated the mar-

47. And in order to form a right Judgment when the Letter of a Statute is restrained, and when enlarged by Equity, it is a good Way, when you peruse a Statute to suppose that the Lawmaker is present, and that you have asked him the Question you want to know touching the Equity, then you must give yourself such an Answer as you imagine he would have done, if he had been present. ... And if the Law-maker would have followed the Equity, notwithstanding the liords of the Law,... you may safely do the like, for while you can do no more than the Law: maker would have done, you do not act contrary to the Law, but in Conformity to it.

Eyston v. Studd, 2 Plowd, 459A, 465, 75 Eng. Rep. (1574), quotel in 3 J. SuritenLilid,

Statutory Construction \$ 6001 (3d ed. 1943).

48. "Equitie" is a construction made by the Judges that cases out of the letter of a statute yet being within the same mischief or cause of the making of the same. shall be within the same remedy that the statute provideth; and the reason thercof is, for that the lawmakers could not possibly set down all cases in express terms.

E. Coke, INSTITUTES $* 24 \mathrm{~b}$.

49. Landis, supra note 34 , at 217.

50. See note 3 supra.

51. Landis, supra note 34 , at 217 .

52. Id.

53. J. SuTHERLAND, supra note 46 , at $\$ \S 6201-06$. 
ried woman to a legal status of virtual non-existence by imposing liability upon the husband for the antenuptial contracts and torts of his wife, by granting the husband ownership of the wife's personal property and income from her realty, and by engaging in the general fiction of the legal identity of the husband and wife. ${ }^{54}$ The Married Women's Acts did not expressly direct any overall change in status, but only in certain of its incidents. That is, these statutes were generally quite brief, merely granting the right to own and convey property, and to sue and be sued. But courts tended to regard the changes in these particular incidents as so fundamental that all other incidents of married women's status had to be radically revised as well.0i

A similar phenomenon involving analogical development of the law occurred in the area of bastardy law. There, the enactment of certain limited intestacy laws granting to illegitimate children the right to maternal inheritance ${ }^{56}$ served to persuade many courts to reevaluate and expand their prior constructions of the word "child" within the terms of statutes regulating wrongful death, wills, workmen's compensation, etc. ${ }^{57}$ Another example of such reasoning mily be found in the area of property law, where courts looked to the standard twenty year statute of limitations for statutorily created rights of adverse possession in order to establish the length of time

54. See 1 W. Blackstone, Commentakies *442, *443.

55. There has been general recognition that the married women's acts cmbodicd principles which were of wider import than the statutes in terms expressed and thus necessitated remoulding common-law doctrines to fit the statutory aims.

Landis, supra note 34 , at 223.

The Nineteenth Amendment has also been regarded at times as cmbodying cutain principles to be given effect beyond the express terms of that amendment. For cxample, in Adkins v. Children's Hospital, 261 U.S. 525 (1923), Justice Sutherland argtied that since the Nineteenth Amendment carried with it the implication that women werc as capable of wresting a living wage as men, legislation establishing minimum wages for women would be unconstitutional.

A quite contrary view of the Nineteenth Amendment secms to have been at work in Justice Harlan's dissenting opinion in Harper v. Va. Bd. of Election, 383 U.S. 663 (1966), according to Franklin, supra note 51, at 493. Franklin accuses Justice Harlan of suggesting that because the Nineteenth Amendment forbids denial of voting rights on the basis of sex, no further extension of voting rights beyond the amendment's explicit directive would be appropriate. Franklin, of course, views the matter differently, and suggests that the Nineteenth Amendment could well have been invoked as an analogy to strengthen the Harper majority opinion.

56. See Note, Illegitimacy, 26 Brooklyn L. Rev. 45, 76.79 (1959).

57. Much like the married woman, the illegitimate child was treated by the common law as a legal non-entity, as a filius nullius. See 1 W. BLAckstone, Commeniraktes 450 . For this reason, courts had generally construed the word "child" when used in the types of statutes referred to in the text, to include only legitimate children. See, e.g., $T$. Aikis. SON, WILLS 81-82 (2d ed. 1953). But after the enactment of the limited intestacy laws, many American courts came to the conclusion, when reconsidering the old common law doctrines in light of the new statutory enactments, that "the analogy of modern statutes rather than the old common law should be resorted to." J. STONE, LEGAL. SYSTEMS AND LAWyers' Reasonings 229 n.102 (1966). See, e.g., Marshall v. Industrial Comm'n, 342 Ill. 400,174 N.E. 534 (1931). 
necessary to establish a right or title by common law prescription.is A final example is the judicial creation of civil liability for criminal conduct. ${ }^{59}$

These and numerous other instances of the judicial use of statutory material as sources of law, lend credence to Landis' conclusion that "there is something intrinsic in the attitude toward legislation that was once phrased by reference to the equity of the statute, that cannot be exorcised from the law." 00 But if Landis is correct that our courts, despite their disavowals, have continued reason by analogy from statutes, then he must also be correct that their failure to explicitly acknowledge this practice has had unfortunate consequences. ${ }^{01}$ This failure has discredited the idea of a "science" of statutory interpretation and has thwarted the development of statutes as generative sources of law.

Since the classic presentations of Pound and Landis, other commentators, both on and off the bench, have echoed their arguments. For example, in 1936 Harlan Fiske Stone urged that coordination of legislative and judicial sources of law was one of the major tasks facing the American legal system. ${ }^{\circ 2}$ Again, in 1956 Walter V. Schaefer, Chief Justice of the Illinois Supreme Court, saw Pound's cvolutionary development continuing and gave it his approval. ${ }^{03}$ Finally, in 1970 Professor Charles L. Black forcefully argued for the adoption of a style of legal reasoning closely resembling the second of Pound's four hypotheses. ${ }^{64}$

Despite the prior development (albeit often disguised) of such analogical reasoning from statutes, Justice Harlan's opinion in Moragne might still be viewed as something of a "sport" in our law. Because of the anomalous and probably unintended predicament confronting Mrs. Moragne and the felt need for a uniform maritime answer to the question of wrongful death recovery, the abundance of language about finding underlying principles in legislation may have been no

58. See Freund, Interpretation of Statutes, 65 U. PA. L. REv. 207, 226 (1917).

59. See Landis, supra note 34 , at 220.

60. Id. at 219.

61. Id.

62. Stone, supra note 4 , at 4.

63. W. Schaffer, Precedent and Policy (1950) quoted in H. Bermax \& W. Greaner, The Nature and Function of Law 356, 360 (1958).

64. See Black, The Unfinished Business of the W'arren Court, 16 WAstl. L. REv. 3, $41-44$ (1970). 
more than a makeweight for the Court's decision. ${ }^{65}$ Such a view of Moragne, however, is belied by the concurring opinion delivered by Justice Harlan on the same day in Welsh $v$. United States..$^{00}$ Justice Harlan's opinion in Welsh suggests that he was quite serious about employing-openly and explicitly-the methodology of finding a principle in legislation and then extending it beyond the express statutory terms.

Welsh concerned the prosecution of a draft registrant who claimed exemption as a conscientious objector and refused induction. His claim to conscientious objector status had been denied because his opposition to participation in war was not based on "religious training and belief," as required by section $6(j)$ of the Universal Military Training and Service Act, ${ }^{67}$ but instead on strong, ethical opposition to such participation. The majority opinion reversed the conviction on the grounds that the exemption had been improperly denied. Following and extending the rationale of United States $v$. Seeger, ${ }^{08}$ the Court held that Congress had used the terms "religious training and belief" in their broadest possible meaning which encompassed a sincerely and deeply held moral and ethical code not in fact based solely on political or sociological considerations..$^{00}$

Justice Harlan, however, refused to perpetuate what he plainly regarded as a charade. He declared that the Court's opinion had only confirmed his fear that he had been wrong in joining the Court's opinion in Seeger five years earlier, and he rejected the attempt to cloak the Court's logic in the language of statutory construction. ${ }^{70}$ $\mathrm{He}$ was convinced that both the language and the legislative history of section $6(j)$ clearly supported the view that Congress meant to distinguish not only between religious and secular objectors, but between theistic and non-theistic "religious" objectors as well. Since Justice Harlan thought Congress' intent was quite clear, he had to face the constitutional question: Could Congress so distinguish with. out running afoul of the religious guarantees of the First Amendment?

65. The Court's decision could have rested on the simple-and justifiable-overruling of precedent alone. See p. 262 supra.

66. 398 U.S. $333(1970)$.

67. 50 U.S.C. App. \& 456(j) (1970).

68. 380 U.S. 163 (1965).

69. The majority opinion employs a rather tortured process of statutory construction in order to arrive at this result. As will be argued shortly, however, this resort to the device of statutory construction frequently occurs when a court views itself as limited to the orthodox common law approach to legislation and the traditional formulation of equal protection analysis. See p. 276 infra. The result in Welsh is far less persuasive than it could have been had the court not viewed its role as so limited.

70. 398 U.S. at 345 . 
That question, he concluded, also had to be answered in the negative. ${ }^{11}$ Having decided that Congress' intent to exempt only theistic believers was unconstitutional, however, Justice Harlan still faced the question of what to do with the petitioner. He recognized that there were at least two possible solutions to the defect of underinclusiveness-first, to strike down the exemption altogether or, second, to extend its benefits to all those who should have been included.: Justice Harlan felt compelled, by the tradition of exempting rcligious conscientious objectors, to take the latter approach and thus join in the result reached by the majority "not as a matter of statutory construction, but as the touchstone for salvaging a congressional policy of long standing that would otherwise have to be nullified."'73

This section of Justice Harlan's Welsh concurrence is a thorough and convincing discussion of the principles that govern judicial discretion to expand the application of a statute beyond its express terms to remedy its underinclusiveness. The judicial task, he observed,

is to simultaneously discern and distinguish "the residual principle in legislation that should be given effect in circumstances not covered by the express statutory terms and the limitation on that principle inherent in the same words." ${ }^{\prime \prime}$

Once this crucial distinction is perceived, a court must then ask whether the legislation in question encompasses all the groups that

71. Congress, of course, could ... climinate all exemptions for conscientious ob. jectors. . . However, having chosen to exempt, it cannot draw the line between theistic or nontheistic religious beliefs on the one hand and sccular beliefs on the other. Any such distinctions are not in my view, compatible with the Establishment Clause of the First Amendment.

398 U.S. at 356.

72. 398 U.S. at 361 . Harlan supports the contention that such alternative solutions exist by citation to dicta in two prior Supreme Court decisions, Skinner y. Okilahoma, 316 U.S. 535 (1942), and Iowa-Des Moines Nat'l Bank v. Bennett, 284 U.S. 239 (1931). In Skinner, the Court found unconstitutionally underinclusive a state statute that required sterilization of habitual thieves who committed larcenies, but not those who embezzled. The Court noted the alternatives of either extending the statute so as to apply to embezzlers as well, or striking it down altogether for underinclusion. In Bennetl, petitioners claimed that their right to equal protection had been violated by being taxed more heavily than their competitors. Justice Brandeis, speaking for the Court, noted that, "The right invoked is that to equal treatment; and such treatment will be attained if either their competitors' taxes are increased or their own reduced." 284 US. at 247. In light of the impracticability of the former solution, the Court simply ordered a refund of the overpayment.

It should be noted, however, that neither Shimner nor Bennelt are in fact approprinte cases for a judicial expansion of legislative terms. Bennett, involving a tax statute, and Skinner, involving a criminal penalty, are examples of two areas in which it is suggested at p. 281 infra that a court would rarely be justificd in extending a statute bejond its express terms.

73. 398 U.S. at 345.

74. Id. at 347 . 
ought naturally to be included.75 Applied to the facts of Welsh, Harlan reasoned that " $[t]$ he 'radius' of this legislation is the conscientiousness with which an individual opposes war in general."7o Having found this common denominator, Justice Harlan was willing to extend the scope of the admittedly underinclusive legislation by insisting that the exemption be applied to the very individuals it purported to exclude. ${ }^{7 \pi}$

\section{VI}

Justice Harlan, in his Welsh opinion, employs what he describes as an "equal protection mode of analysis" 78 to determine whether the statutory exemption given to one class of persons ought to be extended judicially to encompass others. His choice of this label for what has been described in this Note as essentially a civil law method of reasoning, is interesting because our traditional framework of equal protection analysis offers perhaps the closest parallel to the methodology of the civil law. At the same time, the choice illuminates some of the most striking contrasts between the conception of the judicial function in the civil and common law systems. What follows does not purport to be an interpretation, either historical or doctrinal, of the Equal Protection Clause of the Fourteenth Amenclment. The term "equal protection" will be used here, as Justice Harlan used it in Welsh, to illustrate a process of reasoning employed in the traditional mode of analysis associated with that term, rather than to describe the complexities of the "New Equal Protection" of "fundamental interests" and "suspect classifications."70

The standard formulation of equal protection analysis was stated in the classic article of Tussman and tenBroek, "The Equal Pro. tection of the Laws." 80 They sought to develop a systematic analysis of how courts ought to accommodate the conflicting demands of the mandate for equality and the practical legislative necessity of classification. They termed their formulation the doctrine of "reasonable classification" which, simply stated, requires that all those similarly situated with respect to the purpose of a given piece of legislation be similarly treated. ${ }^{81}$ When a statute does not include all who are

75. Id. at 357 .

76. Id.

77. Id. at 358

78. Id. at 357, quoting from Walz v. Tax Comm'r, 397 U.S. 664, 694 (1970).

79. See, e.g., Michelman, Foreword: On Protecting the Poor Through the fourtethlth Amendment, 83 HARv. L. REv. 7, $19-39$ (1969).

80. 37 Calif. L. Rev. 341 (1949).

81. Id. at 344-45. 
similarly situated-that is, when it is underinclusive-"there is a prima facie violation of the equal protection requirement of reasonable classification."s2 Courts, however, have generally allowed easy rebuttal of this prima facie violation. A classification, though discriminatory, is deemed to be neither arbitrary nor violative of the principle of equal protection if any state of facts reasonably can be conceived to sustain it. ${ }^{83} \mathrm{It}$ is not even necessary that the legislature has in fact considered the reason perceived by a court, but only that it might have done so. ${ }^{84}$

It is here that the methodology of civil law systems has its closest relationship to our traditional conception of equal protection. Under our traditional view, underinclusive legislation will be invalidated unless some reasonable justification can be perceived for the legislature's failure to extend the benefits or burdens of that legislation to others who would appear to be similarly situated with respect to the legislation's purpose. But under civil law methodology, the benefits or burdens of a particular piece or course of legislation will be extended to those similarly situated, unless it can be shown that there is no justification for analogous treatment because no sound analogy itself exists. Our inquiry must then be whether these are but two opposite ways of saying the same thing. That is, will the same set of circumstances which would justify a common law court's determination that there was reasonable justification for the statutory classifications established by the legislature also justify the conclusion of a civil law court that there was no sound reason for extending the benefits or burdens of a particular statute beyond its express terms because no sound analogy exists? The answer, it seems, must be negative. Each of the two competing methodologies purports to be firmly rooted in the legislative will. ${ }^{85}$ The common

82. Id. at 348 .

83. See, e.g., Allied Stores of Ohio, Inc. v. Bowers, 358 U.S. 522, 528 (1959); State Bd. of Tax Comm'rs v. Jackson, 283 U.S. 527, 537 (1931); Rast v. Van Deman \& Levis Co., 240 U.S. 342, 357 (1916); Quong Wing v. Kirkendall, 223 U.S. 59 (1912); Lindsley v. Natural Carbonic Gas Co., 220 U.S. 61, 78 (1911).

84. See Railway Express Agency v. New York, 336 U.S. 106 (1949); Williamson v. Lee Optical Co., 348 U.S. 483 (1955); Ely, Legislative and Administrative Molivation in Constitutional Law, 79 YALE L.J. 1207, 1226 n.68 (1970).

No inference is intended here as to the appropriateness of the "reasonable classification" test, or any other test, as valid interpretations of the Equal Irotection Clause of the Fourteenth Amendment. The logical validity of the reasonable classification test has recently come under attack elsewhere. See Note, Legislalive Purpose, Rotionality, and Equal Protection, 82 YALE L.J. 123 (1972). Nevertheles, the Supreme Court shows no signs of abandoning its use. See, for recent examples, Weber v. Actna Casualty \& Surcty Co., 92 S. Ct. 1400 (1972); Police Dept. of City of Chicago v. Mosley, 92 S. Ct. 2280 (1972); Eisenstadt v. Baird, 405 U.S. 438 (1972); Reed v. Reed, 404 US. 71, 75-77 (1971).

85. See J. Stone, The Province and Function of Law 151 (1910). 
law judge, however, employs the presumption that the legislature did consider the excluded class, and chose to exclude it for a valid reason, so long as the court can determine that such a reason does possibly exist. The civil law jurist, on the other hand, will presume that the legislature intended all the logical consequences following from those principles which can be abstracted from a specific legis. lative formulation. ${ }^{86}$ Thus, although both methodologies focus on the same problem of statutory underinclusivity, diametrically opposed (though often fictitious) presumptions are employed regarding legislative intent. As a result, circumstances in which common law courts purport to follow legislative intent by upholding statutory classifications might well lead a civil law court-with equal deference to the presumed legislative will-to expand such classifications.

An obvious question remains. If the presumptions employed by both methodologies are often fictitious and, in any case, evidencc of legislative intent is usually ambiguous or wholly absent, which of these presumptions will most likely lead to results which are analytically persuasive and which respect the coordinate authority of the legislative and judicial processes? American courts have traditionally viewed the choices before them as limited either to striking down underinclusive legislation altogether or finding some justification for sanctioning its classifications. Therefore, they have been willing to bend far to find some basis for the legislature's action in order to defer to its coordinate authority and avoid the charge of "judicial legislating." But if the choices before the courts are not so limited and legislation can be judicially expanded so as to provide the same burden or benefit to parties not expressly covered by the legislation (but analogously situated), then our courts may not always have been deferring to the legislative will by so narrowly perceiving their own role.

A recent example should make this point clear. Sweney Gasoline of Oil Co. v. Toledo, Peoria \& Western R.R., ${ }^{87}$ involved an action by the lessee gas company for damages to leased premises caused by the negligent derailment of a train belonging to the lessor railroad. The lease agreement between the parties contained a clause exculpating the lessor railroad from liability for damage caused by its own negligence. Illinois common law recognized the general validity of exculpatory clauses in leases. ${ }^{88}$ But in 1959 the Illinois legislature had

86. Id. at 151-52.

87. 42 Ill. 2d 265, 247 N.E.2d 603 (1969).

88. O'Callaghan v. Waller \& Beckwith Realty Co., 15 Ill. 2d 436, 155 N.E.2d 545 (1958). 
attempted to overturn this common law rule through legislation which declared void all exculpatory clauses in leases, "except those business leases in which any municipal corporation, governmental unit, or corporations regulated by a State or Federal Commission or agency is lessor or lessee . . ." When the lessee gas company brought an action for damages, the railroad set up in defense the lease clause, and the protection of that clause embodied in the exception to the statute. Agreeing with plaintiff's argument that the statutory exception of governmental units and regulated corporations was discriminatory and without any reasonable basis, the Illinois Supreme Court held for the defendant railroad nonetheless. Because the statute created an unconstitutional discrimination by granting a preferred status to regulated corporations, the court reasoned that the statute as a whole was void. ${ }^{90}$ There being no remaining statute to regulate the field, the court looked for its answer in the common law which, as previously suggested, recognized the validity of exculpatory lease clauses. Thus, the net effect of the legislative effort to overturn the common law rule was absolutely nil.

Justice Schaefer ${ }^{91}$ dissented on the grounds that although the statute as written was unconstitutional, it nevertheless served as an "expression of public policy which fully justifies this court in now holding, as a matter of common law, that exculpatory clauses in leaseholds are void." 92 His willingness to accord the policy behind the statute precedence over the older common law rule (unconstitutional though the statute was as enacted) is yet another example of the first of Pound's four hypotheses regarding judicial treatment of legislation. ${ }^{93}$ Like Justice Harlan in Welsh, Justice Schaefer believed that the constitutional difficulty inhered not in the statute itself, but in the exemption from the statute's requirements. Eliminating the exemption through analogical expansion of the statute's principles could cure the constitutional defect and give effect to the general legislative will in its most recent and direct expression.

The majority of the Sweney court was unable to achieve the same

89. Law of April 13, 1959, p. 98, § 1 [1959], Ill. Laws 1959, replaced by ILL. LNN. StıT. ch. 80, \$ 91 (Smith-Hurd 1972).

90. The court did not further elaborate its reasons for believing that the statute's classification had no rational relation to its statutory purpose. For the present analysis, however, it is not important whether the equal protection rationality test was correctly applied, but only that the court purported to be using it.

91. Justice Schaefer is well aware of the potentialities of analogical reasoning from statutes. See note 63 supra.

92. 42 Ill. 2d at 269, 247 N.E.2d at 606 (emphasis added).

93. See p. 265 supra. 
result through utilization of traditional equal protection methodology. Once the court had decided that there was no conceivable justification for drawing a line between regulated and non-regulated corporations, the statute was treated as if it was totally devoid of any generative influence. The court argued for deference to the legislature but refused to accord the statute any significance because it had "no way of knowing whether the legislature would have enacted the statute without the fatal exceptions." 94

This approach, it must be recognized, leads to embarrassing results precisely because the court has refused to ask the only important question. Is there a "residual principle" that remains in a piece of legislation, even after a constitutional defect has been discovered in it, and should a court give effect to that principle despite the defect? The court in Sweney, while ostensibly refusing to ask this question, in effect answered it in the negative. But it is hardly judicial deference to negate entirely the effect of a legislature's actions and then require the probable ritual of enacting a new statute without the troublesome exemption. Whether the Sweney court's decision would have been different if it had actually undertaken the inquiry suggested here is immaterial. It is only important to point out that the inquiry should have been undertaken. Under either approach, the legislature would remain free to change the court's result if it found it unsatisfactory. And in Sweney it did. In 1971 the Illinois legislature did what the Illinois Supreme Court thought itself incapable of doing and declared all exculpatory lease clauses void. ${ }^{95}$ Thus, in at least some cases the analogical methodology under discussion involves no more (and possibly less) "judicial legislating" than the traditional equal protection approaches.

If our common law courts in fact are not restricted to a choice between overturning arguably underinclusive legislation or search. ing for some conceivable rationale by which to sanction it, then a third course is open to them. The terms of an underinclusive statute can be expanded so as to encompass all parties analogously situated with respect to the principles embodied in the express terms of the statute. If this course is followed, then a great many cases which have been argued and decided on other grounds can perhaps be better explained and understood in terms of the type of analysis suggested here.

94. 42 Ill. $2 d$ at 270,247 N.E.2d at 606 .

95. ILL. ANN. STAT. ch. 80, $\$ 91$ (Smith-Hurd 1972). 
In Moragne, for example, there would surely seem to be some conceivable justification under a traditional equal protection approach for the classifications established in each of the relevant wrongful death statutes. Where a court is not necessarily constrained by the express terms of those same statutes, however, that consideration does not foreclose an inquiry as to whether those statutes, taken together, embody a principle which would be served by extending their remedy to the petitioner before the court.

In this regard Moragne is reminiscent of a much earlier admiralty decision, International Stevedoring Co. v. Haverty, ${ }^{00}$ which held that the Jones Act, which was expressly applicable only to "seamen," was equally applicable to longshoremen. Here again, the Court might have been able to reach the same result in a more persuasive manner through the expansive process of analogical reasoning from statutes. But without even considering the case in terms of an equal protection mode of analysis, and confined within the limits of traditional common law methodology, the Court was compelled to employ a very dubious process of statutory construction to bring the plaintiff within the Jones Act's ambit. ${ }^{97}$

Other examples of an expansive "statutory construction" approach to get around results which would have been dictated by traditional equal protection analysis are not difficult to find. Girouard $v$. United

96. 272 U.S. 50 (1926).

97. In Haverty it was very important for the plaintiff longshoreman to assert his claim under the recently enacted Jones Act which, for its remedies, abolished the common law defense of "fellow servant," a defense which would otherwise have prevailed over Haverty's claim. The problem, however, was that the Jones Act applied only to "seamen," a term which, prior to Haverly, had been almost uniformly assumed to refer to those who actually man ships and not to longshoremen. See G. GiLsore \& C. BLACs, supra note 12, at 358. Moreover, Haverty was without any remedy under a state workmen's compensation act because the application of such acts to longshoremen had twice been held unconstitutional by the Supreme Court. Knickerbocker Ice Co. V. Stcwart, 253 U.S. 149 (1920); Southern Pacific Co. v. Jensen, 244 U.S. 205 (1917).

Even if the Court had considered the possibility, a solution to Haverty's dilemma could not easily have been found within the framework of an equal protection mode of analy: sis. It surely would not have been difficult to conceive of some rational justification for granting certain benefits to seamen and not to longshoremen. Thus, in an effort to find a remedy for Haverty, the Court was forced to ignore altogether the long-standing connotation of the term "seamen," and reason that since modern longshoremen perform Iasks traditionally done by "seamen," that word would be construed in the Jones Act to encompass longshoremen as well. What the Court purported to do by "statutory construction" in Haverty was, in effect, an extension by analogy of the Jones. Iet to a class of workers probably not within the contemplation of the Congress when it passed that act. The Court's creative result was clearly necessary, however, for as Gilmore and Black have observed,

without something like Haverty, this class of worker [longshoreman], and this class almost alone in the entire country, would have found its recovery for unavoidable industrial accidents barred by the harsh nineteenth century rules of fellow servant and the like.

G. GILMORE \& C. BLACK, supra note 12 , at 361 . 
States $^{98}$ can be understood in these terms. There, the Supreme Court was faced with the petition for naturalization of an alien conscientious objector. The Court overruled its own clear precedent that such aliens could not be naturalized by inferring a principle that would allow naturalization from certain legislative enactments which did not, by their express terms, even apply to the petitioner before the Court.99

Each of the above cases is offered simply as an instance in which our courts have invoked the language of "statutory construction" to reach results which would seem more understandable and persuasive if recast in terms of reasoning by analogy. Why, then, have American courts so often cloaked such analogical reasoning in a misleading doctrinal guise? The answer seems to lie in certain doubts which American judges have concerning the scope of their powers in relation to legislation. Tussman and tenBroek have advocated the nearly standardless "any conceivable justification" criterion of equal protection analysis in part because of their belief that " $[\mathrm{t}] \mathrm{he}$ legislature, after all, has the affirmative responsibility. The courts have only the power to destroy, not to reconstruct."100 But civil law methodology, while incorporating extensive judicial discretion with respect to legislation, may in some cases be more faithful to the general legislative will than would traditional equal protection methodology.101 Justice Harlan's concurrent opinions in Moragne and Welsh, moreover, strongly suggest that American courts can legitimately exercise such an expanded role with respect to legislation.

98. 328 U.S. 61 (1946).

99. The problem in Girouard was the following: part of the naturalization process was the taking of an oath to "support and defend the Constitution and laws of the United States of America against all enemies, foreign and domestic." Nationality Aet of 1940 , ch. 876, \& 335, 54 Stat. 1157, as amended, 8 U.S.C. \$ 1448(a) (1970). Thrce prior decisions of the Supreme Court squarcly stood for the proposition that an alien who refused to bear arms could not be admitted to citizenship. United States v. IBland, 283 U.S. 636 (1931); United States v. Macintosh, 283 U.S. 605 (1931); United States v. Schwimmer, 279 U.S. 644 (1929). Despite a vigorous legislative attempt to overrule the effect of those decisions, the naturalization statutes and the oath requirement had been rechated in the same form as when the previous cases were decided. Congress had also, however, in certain 1942 amendments to the Nationality Act of 1940, Second War Powers Act, ch. 199 , \$ 701, 56 Stat. 182 (1942), as amended, 8 U.S.C. $\$ 1440$ (1970), relaxed certain of the naturalization requirements for aliens who had served honorably in the armed forces during World War II. These amendments had been construcd to apply even to those who had served as non-combatants. See, e.g., In re Sawyer, 59 F. Supp. 428 (D. Del. 1945); In re Kinloch, 53 F. Supp. 521 (W.D. Wash. 1944). Although this legislation did not expressly apply to the petitioner, the Court nevertheless concluded that it cmbodied the principle that "one could be attached to the principles of our government and could support and defend it even though his religious conviction prevented him from bearing arms." 328 U.S. at 70. Extending this principle to the petitioner, the Court found no reason to deny him citizenship, and thus overruled its own precedent.

100. Tussman \& tenBroek, supra note 80, at 373.

101. See pp. $274-76$ supra. 


\section{VII}

If Justice Harlan's opinions in Welsh and Moragne are read as accepting into common law jurisprudence a style of judicial reasoning closely patterned on the civil law methodology of reasoning from statutes by analogy, then it seems necessary to set forth some of the considerations which determine whether, in a given case, utilization of the methodology is appropriate. As has already been made clear, the legal methodology discussed in this Note is quite unfamiliar to many whose training is solely in the common law. A possible danger, therefore, is that the very unfamiliarity of the doctrine will give it an immediate superficial attractiveness. Initially grasped, the methodology seems capable of giving almost any solution desired for a particular problem. For that very reason it is doubly important to suggest some of the parameters of the methodology and some of the very weighty restraints upon its use.

One of the most fundamental considerations to be kept in mind is that the civil law conception of the legislative function differs substantially from the accepted American view of that function. In both systems it is the legislature's job to adjust and regulate competing interests. ${ }^{102}$ But in civil law systems, such as those of France and Germany, that adjustment is viewed by the courts as a legislative attempt to formulate a complete body of principles and concepts in the form of a Civil Code "so as to furnish a legislative basis for juristic and judicial development along modern lines." 103 Often, these principles are stated in very general terms rather than with the precise particularity of most American legislation. Also, the civil law view of legislation, or at least that part of it which is incorporated in the Civil Codes, must necessarily assume a sort of permanency, while the traditional American view assumes that legislation may be amended or repealed at any time and is therefore relatively transient. In this regard the legislation of a European Code might usefully be likened to a constitution. ${ }^{104}$ Thus, legislation in civil law countries is drafted with a view to the fact that it will be used by the courts as a source of law to be reasoned from by analogy, ${ }^{105}$ or so the courts presume.

102. See P. HECK, BeGrifFsBILDUNG UND INTERESSENJURISPRUdeNz (1932), quoted in THE JURISPRUdence OF INTERESTS: Selected W'RTtives 102-01 (MI. Schoch ed. 1948).

103. Pound, supra note 43 , at 71 .

104. See F. LAwSON, supra note 42 , at 55-61.

105. The first draft of the German Civil Code contained the following:

Relationships for which the code does not contain any provisions are to be regu-

lated by the corresponding application of the provisions applicable to similar legal 
This view of the legislative function seems to contradict the generally accepted pressure group theory of legislation in the United States. We simply do not demand that our legislatures treat all analogously situated parties in identical ways. Therefore, to suggest that the courts ought to extend the principle of a certain piece of legislation to other analogous interests not actually provided for by statute seems to ring of usurpation, when the reason for not so extending the statute stems solely from political factors already considered by the legislature. Any adoption of civil law methodology must inevitably take this factor into account. It should be recalled, however, that commentators also have recognized the incompatibility of the pure pressure theory of legislation and the requirement of equal protection. ${ }^{106}$ The argument is essentially that between the conception of equal protection as a generalizing requirement set forth by Justice Jackson in Railway Express Agency, Inc. v. New York ${ }^{107}$ and the various attacks made upon that conception. ${ }^{108}$ The argument cannot be renewed here; but any effort to use the methodology of analogical reasoning from statutes in our legal system must ultimately deal with the widely held view of legislation as the accommodation of clashing interests rather than the embodiment of logical principles. ${ }^{100}$ There are, for example, certain areas of our law where courts have traditionally construed legislative language quite

relationships. In the absence of such provisions, the provisions arising from the spirit of the legal order are to be applied.

This language was omitted from the second draft of the Code because it was felt to be obvious and unnecessary, no special provision for the use of analogy being required. Sect F. REATZ, ENTWURF EINES BURGERLICHEN GESETZBUCHS (1894), quoted in A. VON MEIIREN, supra note 44 , at 65 .

106. See, e.g., Tussman \& tenBroek, supra note 80, at 350 .

107. Invocation of the equal protection clause... does not disable any govern. mental body from dealing with the subject at hand. It merely means that the pro.

hibition or regulation must have a broader impact. . . [T] [Tere is no more effective practical guaranty against arbitrary and unreasonable government than to require

that the principles of law which officials would impose upon a minority must be imposed generally.

336 U.S. 106, 112 (1949) (concurring opinion).

108. See, e.g., A. Bicket, The LeAst DANGerous Branci1 225.26:

[Our legislatures] are political institutions, and we should not require them also to be disinterested; they are indeed the formm for clashes of interest.

109. It is not at all clear what judicial consequences flow from an acceptance of the pure pressure theory of legislation. For cxample, in the fairly frequent casc in which legislative history is either wholly absent or ambiguous, courts can only look to the tcrms of a statute in construing it. Moreover, even where some legislative history is avallable, courts are often asked to decide what a legislature would have done had it known that the statute, as enacted, would contain some constitutional defect. Welsh and Su'eney arc examples of this latter situation. See pp. 271-72, 275-76 supra. In cither situation the pure pressure theory of legislation does not seem to dictate any one judicial response. Absent legislative direction, courts ought to be free to reach results which are both analytically sound and logically persuasive. The methodology or reasoning from stattites by analogy may, in many cases, be best suited to achieve such results. See pp. 279.74 supra. 
narrowly and must continue to do so. Quite obviously, criminal statutes are drawn with a specificity of purpose and must be aimed at clearly defined conduct. One essential component of political liberty is that a citizen know when the conduct in which he is engaged is unlawful.110 Also, analogical reasoning from statutes should not negate the familiar canon of statutory construction whereby those constructions are avoided which would render a statute unconstitutional. ${ }^{111}$ Finally, the analogical methodology would probably also be inappropriate in such areas as tax legislation, where the laws are expected to be drawn with such specificity that the taxpayer can legitimately take advantage of whatever "Ioopholes" are available, and where the legislature is quite clearly and permissibly favoring or disfavoring one specific interest over another. ${ }^{112}$

But just as there are some areas in our law where the methodology is inappropriate, so there are other areas which seem ripe for its use. In the last several decades, the American legal system has itself been codifying its rules in the form of various uniform laws and restatements. In part, these represent nothing more than an effort to systematically arrange and restate old common law principles. Yet at times there is also an effort to depart from and change the prior judicially-created rules. Where this latter attempt is made, our courts ought not try to harness codifying innovation with the trappings of the old common law. The change clearly represents a dissatisfaction with the old common law authority, and here the courts ought to be liberal in reasoning from legislation by analogy, rather than clinging tenaciously to the disfavored common law rules. ${ }^{113}$

Another area in which the methodology described here could be employed extensively is in the area of landlord and tenant law. Like all other areas of American property law, the law of landlord and

110. See J. SUTHERLAND, supra note 47 , at $\$ 5004$.

111. See Haynes v. United States, 390 U.S. 85, 92 (1968); Schneider v. Smich, 390 U.S. 17, 27 (1968); United States v. Rumely, 345 U.S. 41, 45 (1953); Ashwander v. Tennessec Valley Authority, 297 U.S. 288, 348 (1936) (Brandeis, J., concurring); Crowell v. Benson, 285 U.S. 22, 62 (1932).

112. On the inappropriateness of traditional equal protection analysis to taxing legislation see Ely, supra note 84, at 1235-48.

Even here, however, the rule of strict interpretation may not always be applied. See, e.g., Reich v. Commissioner of Internal Revenuc, 454 F.2d 1157 (9th Cir. 1972). a/f'g 52 T.C. $700(1969)$, in which, again by a tortured process of "statutory construction," the oil and gas depletion allowance was held to be available to a power company extracting gio. thermal steam from the earth.

113. See Beutel, The Necessity of a New Technique of Interpreting the Negotiable Instruments Law: The Civil Law Analogy, 6 TUL. L. REv. 1 (1931); Franklin, The Historic Function of the American Law Instilute: Restatement as Transitional to Codification, 47 Harv. L. REv. 1367 (1934); Franklin, On The Legal Mielhod of the Uniform Com. mercial Code, 1951 Law \& Contemp. Prod. 330. 
tenant has been dominated by judicially-created common law rules. Growing dissatisfaction with some of these common law results has led to the adoption of remedial legislation, often in the form of housing codes. There is at least some indication that courts will view this legislation as an indication of dissatisfaction with the common law and hence as a source of new principles to be applied more broadly. ${ }^{114}$

The methodology has already been used, in a slightly different way, by federal courts when faced with the task of determining some of the incidents of a federal cause of action. Typically, this takes the form of utilizing state statutes of limitation applicable to analogous types of claims to define the limitations of federal rights of action for which no federal statute of limitations has been provided.115 This type of process seems almost inevitable where new federal causes of action are created, either legislatively or judicially.110

The above are meant only to be suggestive of the sorts of areas in our legal system where the methodology of reasoning by analogy from statutes can usefully be employed. Certainly, the short list pro. vided is not exhaustive. Indeed, arguments based on statutory analogy will probably appear to some degree in nearly all areas of our law. When used, however, the argument must necessarily be met with a number of other objections in addition to those fundamental constraints considered in the first paragraphs of this section.

In this regard, Justice Harlan's opinion in Welsh, by its very thoroughness, is suggestive of many of the restraints upon reasoning from statutes by analogy. Broadly speaking, these restraints can be grouped into two general categories. The first and perhaps most fundamental are those purely formal restraints which inhere in any

114. See, e.g., Pines v. Perssion, 14 Wis. 2d 590, 595.96, 111 N.W.2d 409, 412.18 (1961). 115. See, e.g., Cope v. Anderson, 331 U.S. 461 (1947); Campbell v. Haverhill, 155 U.S. 610 (1895); but see Holmberg v. Armbrecht, 327 U.S. 992, 395 (1946).

116. This very point was raised, but left unresolved, in Moragne. The Court there, in effect, created a federal cause of action under the general maritime law for death caused by breach of a maritime duty, but left open the many questions pertaining to the exact nature of the remedy so created, e.g., the applicable statute of limitations, the question of which beneficiaries are entitled to recover, the question of whether recovery for such non-pecuniary losses as pain and suffering and loss of consortium would be allowed, the effect of contributory negligence, etc. As the Court recognized, these incidents will have to be borrowed from one or more of the related statutes (the Death on the High Seas Act, the Jones Act, the Longshoremen's and Harbor Workers' Act, or a state wrong. ful death statute) according to whichever provides the best analogy. See $\$ 98$ U.S. at 405 . 08. The government argued as amicus curiae, and the Court seemed to suggest, that the Death on the High Seas Act furnished the best analogy from which to draw these incidents. The lower courts have generally followed this lead but have not done so uniformly. Compare Guilbeau v. Calzada, 240 So. 2d 104 (La. Ct. App. 1970) with Dennis v. Central Gulf Steamship, 323 F. Supp. 943 (E.D. La. 1971) and Thomas v. C. J. Langenfelder \& Son, 324 F. Supp. 325 (D. Md. 1971). 
system of analogical reasoning. Reasoning by analogy from statutes requires all the subtleties and rigors of logic that reasoning from case law requires. "Analogy" must mean more than simply ukase. The strength of the system depends upon its devotion to principle. And just as the legislature may overrule a decision developed through the complexity of common law reasoning, so it may overrule a decision reached through the methodology of reasoning by analogy from prior legislative enactments. And finally, though the pursuit of this methodology is to find analogies, the existence of distinctions must also be kept in mind. ${ }^{117}$

The second set of limitations derive more or less from the problem of correctly ascertaining legislative intent. This point was raised earlier in the discussion of Sweney, and deserves reemphasis because of its general nature. Every effort to perceive in legislation one or more principles intended to have application beyond the express terms of the legislation, must confront the argument embodied in the maxim expressio unius est exclusio alterius. ${ }^{118}$ By this maxim, the legislature's failure to make a statute applicable in other circumstances or to other parties implies an intent by the legislature that the statute should not be applied in those other circumstances or to those other parties. But to apply this maxim to the face of every statute is to engage in a fictional presumption. An intent to exclude can never be proven by the mere failure to include. This is a question on which only the legislative history can shed light. If it can be shown that the legislature either did not consider the application of the legislation in the particular circumstances, or that it could not have because those circumstances were plainly unforeseeable at the time, then the maxim should carry no weight at all.

Another aspect to the problem of determining the restraint imposed by legislative intent is the following:

The axiom that courts should endeavor to give statutory language that meaning that nurtures the policies underlying legislation is one that guides us when circumstances not plainly covered by the terms of a statute are subsumed by the underlying policies to which Congress was committed. Care must be taken, however, to respect the limits to enact a particular policy, especially when the boundaries of a statute are drawn as a compromise resulting from the countervailing pressures of other policies. ${ }^{119}$

117. See Black, supra note 64 , at 42 .

118. "Expression of one thing is the exclusion of another." See also J. Sutruerlasd, supra note 47 , at $\$ 6104$.

119. United States v. Sisson, 399 U.S. 267, 297-98 (1970). 
While the idea conveyed in the quoted passage is that narrow, literal reading is required of legislation that results from compromises between powerful contending forces, it seems directly contradicted by the following consideration:

The familiar rule that a thing may be within the letter of the statute and yet not within the statute, because not within its spirit nor within the intention of its makers ... has particular application in the construction of labor legislation which is to a marked degree, the result of conflict and compromise between contending forces and deeply held views on the role of organized labor in the free economic life of the Nation and the appro. priate balance to be struck between the uncontrolled power of management and labor to further their respective interests. ${ }^{120}$

Perhaps the best example of an instance in which the restraint suggested by the first passage quoted above has been blithely ignored is in United States v. Hutcheson.121 There, Justice Frankfurter, speaking for a divided Court, decided that the Norris-LaGuardia Act, ${ }^{122}$ though in terms concerned only with injunctions, also exempted labor unions from civil or criminal prosecution under the antitrust laws. Authors of the Norris-LaGuardia Act (of whom Frankfurter was one) had been at pains to secure its passage through repeated assurances that the act would not affect any of the judicial remedies otherwise available in labor disputes. ${ }^{123}$ Frankfurter's rare show of judicial non-restraint exposed him to bitter ad hominem attacks and led one commentator to remark that, "The majority opinion displays a boldness of judicial technique seldom to be observed,"124 and to suggest further that the whole opinion be treated as dicta, while adopting a concurring opinion as the rule of the case. ${ }^{225}$ Though it may not have been appropriate in the particular case, it can hardly be said that the judicial technique employed was exceptionally bold.

As the Harlan opinions in Moragne and Welsh clearly show, these limitations need not bar the explicit use of analogical reasoning from statutes. Nevertheless, it is difficult at this point to assess the impact of Moragne and Welsh on American law. Perhaps these opinions re-

120. National Woodwork Mfr's Ass'n v. N.L.R.B., 386 U.S. 612, 619 (1967) (citations omitted).

121. 312 U.S. 219 (1941).

122. 29 U.S.C. $\$ \S 101-15(1970)$.

123. See Frankfurter \& Greene, Congressional Power Over the Labor Injunction, 31 ColuM. L. Rev. 385, 408 (1931).

124. Gregory, The New Sherman-Clayton-Norris-LaGuardia Act, 8 U. Cur. L. REv. 503 (1941).

125. Id. at 512 . 
flect no more than an unexpected turn in Justice Harlan's thinking near the end of his distinguished career. ${ }^{120}$ If so, his untimely departure from the Court only a year later may mean that we shall never benefit from the full fruition of his thinking in this area. Perhaps, however, these opinions reflect a more broadly based feeling within the legal profession that the time has come for open acceptance of a long-ignored method of legal reasoning. Justice Harlan's opinions would seem more appropriately viewed in this latter context, as evidence of the evolutionary development which Dean Pound recognized as inevitable at the beginning of this century. Thus, further development and refinement of this style of reasoning need not await additional elaboration by the Supreme Court. The methodology is a tool ready to be used by judge and advocate alike throughout our legal system. Without it, the task of harmonizing and rationalizing our system of law will remain insuperable.

126. In this context, it is interesting to note Justice Harlan's concurring opinion in Griswold, where he refused to accept the penumbra concept of Justice Douglas. See notc 45 supra. See also Professor Franklin's criticism of Justice Harlan's reasoning in Harper v. Bd. of Elections, supra note $\mathbf{5 5}$. 